\title{
凍結乾燥ヤマノイモの粘度に及ぼす要因
}

\author{
田之上隼雄*・鮫島陽人*・下園英俊*・市来征勝*
}

\section{Factors Affecting the Viscosity of Freeze-dried Yam}

\author{
Hayao Tanoue*, Yuto Sameshima*, Hidetosi Shimozono* \\ and Masakatsu ICHIKI* \\ * Kagoshima Prefectual Agricultural Experimental Station. \\ 500 Kamifukumoto-cho, Kagoshima-shi, Kagoshima 891-0166
}

\begin{abstract}
Factors which affect the viscosity and viscous polysaccharide of freeze-dried yams were investigated. (1) Three kinds of yam (Jinenjo (Dioscorea japonica). Thukune-imo (D. opposita) and Soro-yam (D. alata L.)) were freeze dried. The viscosity of freeze-dried Soro-yam was the highest. The decrease of the content of viscous polysaccharide in freeze-dried yams was most remarkable in Jinenjo. The sucrose content in Jinenjo was less than that in Soro-yam, suggesting that the sucrose content in yams affects the viscosity of freeze-dried yam bacause sucrose addition stabilized the viscosity of freeze-dried Jinenjo. (2) The change of viscosity was minimal during freeze drying, while there was a significant decrease in the content of viscous polysaccharide during storage. As storage temperature was increased, the viscosity of freeze-dried yam decreased during storage. Freeze-dried yam wrapped in nylon-polyethylene laminate absorbed water during storage. Water absorption of dried yam accelerated the viscosity change. (3) The viscosity of freeze-dried yam acidified before freeze drying decreased as the $\mathrm{pH}$ of the yam was lowered. (4) Viscous polysaccharide was purified with SDS-ethanol and freeze dried. During storage at room temperature, freeze-dried viscous polysaccharide changed from water-soluble to water-insoluble. It was ascertained that polysaccharide insolubility was one of the sources of the viscosity change of freeze-dried yam.
\end{abstract}

(Received Aug. 4, 1997 : Accepted Dec. 22, 1997)

ヤマノイモの粘性の本体は糖タンパクと言われてお り，その化学的性質やレオロジーについては数多くの報 告がある

その特有の粘性は, 生食として食する「トロ口」や菓 子, 糆類など加工食品の物性改良剤として幅広く利用さ れている、ヤマ/イモは生芋, 冷凍卜口ロ, 凍結乾燥粉 末として供給されるが，ヤマノイモの乾燥粉末はその簡 便性が評価され，利用が増加している，民間調査機関の 調查によると, 1989 1992 年における凍結乾燥粉末の生 産量の年率の伸びは 7〜8\% で, 1992 年度における生産 量は 490 トンとなっている. しかし一方，ヤマノイモの 乾燥粉末が生鮮ヤマノイモ本来の粘性を有しているとは
言えず，市販品の品質にもバラッキがあるなど問題点も 指摘されている.

凍結乾燥ヤマノイモの粘性低下は乾燥過程や眝蔵中に 起こることが報告されているが(10)11)，その機構について の詳細は明らかでない.

そこで, ヤマノイモの粘性を最むよく保持すると言わ

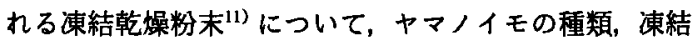
乾燥条件，粉末の盯蔵条件等が粘性変化に及ぼす影響と 凍結乾燥粉末におりる粘質多糖の挙動について検討し た. 


\section{材料および方法}

\section{1. 材 料}

ジネンジョ (Dioscorea japonica Thunb), ックネイ モ (D. opposita Thunb) 及び南方から導入されたソロ ヤム（D. alata L. に属し，導入した鹿児島大学での整理 番号 $\mathrm{KaU}-09$ が付けられ，登録品種でないがソロヤムと 呼称されている）の 3 種類を用いた. ジネンジョは自生 していたもので，掘取り後 2 日目に供試した。 ックネイ モは市場出荷品を購入し，ソロヤムは鹿児島県農業試験 場で栽培, 収模された。

\section{2. 凍結乾燥粉末の調繁}

剔皮したヤマ/イモを約 $3 \mathrm{~mm}$ 厚みの輪切りとし， ス テンレス製バット上に $3 \sim 5 \mathrm{~cm}$ 厚さに広げ， $-20^{\circ} \mathrm{C}$ の 冷東庫で予備凍結した。

東結乾燥装置として実用規模の機種（日立製作所製） を用い，棚温度 $40^{\circ} \mathrm{C}$ ，コールドトラップー35〜 $-20^{\circ} \mathrm{C}$, 真空度 $0.2 \sim 0.3$ Torr の条件で 48 時間乾燥して凍結乾燥 品を試作した。乾燥品は粉砕し，粉末とした。

一部の試験では「トロロ」にしてから涷結乾燥した。 この場合, 剝皮したヤマノイモを変色防止剤の溶液を滴 下しながらステンレス製卸し金で指り卸した後，変色防 止剤が均一になるようにミキサーで緩やかに混練（約 5 分）してトロロを調製した. トロロはバット上に $3 \mathrm{~cm}$ 厚さに広げ, 同様に予備凍結, 凍結乾燥した。

\section{3. 精製粘質多糖の調製6)}

生鮮ジネンジョの水抽出液に Sodium Dodecyl Sulfate (SDS) を加え, タンパク質を沈殿, 除去した後エタ ノールで粘質多榶を沈殿回収する方法を 5 回繰り返し， ゲル澺過的に単一ピークとした，精製粘質多糖中の炭水 化物，タンパク質量をフェノール硫酸法，ケルダール法 によって求めた．またその赤外吸収スペクトルは $\mathrm{KBr}$ 錠剤法によって，HORIBA FT-200を用いて测定した。

\section{4. 粘度測定}

(1) 見掛け粘度

凍結乾燥㸮末に, 凍結乾燥前の生鮮物ヤマノイモの水 分含量となるように水を加え，時々ガラス棒で摫拌しな がら $5^{\circ} \mathrm{C}$ で 24 時間放固して水戻しした．その $10 \mathrm{~g}$ に水 $20 \mathrm{~m} l$ を加え，スターラーで約 1 時間筧拌し，遠心分離 （10000 rpm，15 min）した上澄液を検液とした．あらか じめ $25^{\circ} \mathrm{C}$ に保温しておいたデジタル式 $\mathrm{E}$ 型粘度計（東 京計器) の試料室に検液 $1 \mathrm{~m} l$ をいれ, ローターをセット してから5分後にローターを回転させ，1 rpmにおける 見掛け粘度を読み取った。

\section{(2) 相対粘度}

精製した粘質多糖の $0.01 \%$ 水溶液について測定した が, オズワルド粘度計（水の流下時間 345 秒）を用いた。

\section{5. 粘質多糖含量}

4. (1) の方法で水戻ししたヤマノイモ $10 \mathrm{~g}$ に約 $30 \mathrm{ml}$ の水を加えて混合した後遠心分離した. 沈殿物に水を加 えて混合, 遠心分離する操作を繰り返し，上澄液 $100 \mathrm{ml}$ を得た，上澄液 $10 \mathrm{~m} l$ を，前報12) の方法に準じて， Toyopearl HW-65, HW-75，HW-40を連結したゲル湮 過カラムに注加した。 $0.4 \mathrm{MNaCl}$ で溶出し，粘質多糖の 溶出画分をフェノール硫酸法で比色定量した。

\section{6. トロロの物性測定 ${ }^{12)}$}

水戻しした乾燥粉末 $250 \mathrm{~g}$ を $300 \mathrm{ml}$ 容ビーカーにと り，この中に $\mathrm{T}$ 型フックを差し込んだ. 引っ張り試験機 （東洋ボールドゥィンCTM-100）でフックを一定速度 $(500 \mathrm{~mm} / \mathrm{min})$ で引き上げ, トロロの糸が切れるまでの 仕事量 ( $\mathrm{S}$ 值) と距離 ( $\mathrm{L}$ 值) を求めた.

\section{7. 貯蔵方法}

凍結乾燥粉末 $15 \mathrm{~g}$ を $8 \mathrm{~cm} \times 10 \mathrm{~cm}$ のアルミ・ポリエ チレンラミネートフィルムとナイロン・ポリエチレンラ

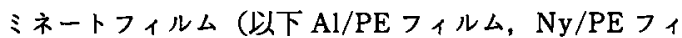
ルムと記す）袋に入れ，ヒートシールした後, 室温付近 $\left(20^{\circ} \mathrm{C}, 15^{\circ} \mathrm{C}\right)$, 低温 $\left(8^{\circ} \mathrm{C}, 5^{\circ} \mathrm{C}\right)$ および令凍域 $\left(-20^{\circ} \mathrm{C}\right)$ 下で眝蔵した。

\section{結果および考察}

\section{1. 各種ヤマノイモ東結乾燥粉末の品自}

ヤマノイモを卸し金で捪り卸して調製したトロロの物 性值（引っ張り試験における S 值，L值）の異なるジネ ンジョ（水分含量 $69.3 \% ， \mathrm{~S}$ 值 $171 ， \mathrm{~L}$ 值 12)、ックネイ モ（水分含量 $70.1 \%, S$ 值 49, L 值 5), ソロヤ厶（水分 含量 $87.3 \%, \mathrm{~S}$ 值 $117, \mathrm{~L}$ 値 11) の凍結乾燥粉末および 3 種類の市販品（製造年月日，品種は不明）の見卦け粘度 をTable 1 に示した. 見掛け粘度は全て水分含量がソ口 ヤムの生鮮物の水分含量である $87.3 \%$ になるように水 戻しして測定したが，製品間で大きく異なった。ソロヤ ムの粘度が他の製品に比べて著しく高いのが特徽的で, 生鮮物では粘りの強かったジネンジョはックネイモとは ば変わらない粘度を示し, 凍結乾燥状態での粘度低下の 大きいことが同えた。

市販品は，3 種類とも前歴は不明であるが，いずれも 粘度は低加った。ヤマノイモの粘度と菓子原料適性にっ いては, 粘度の高いヤマノイモで老化の遅い良質のかる かん（蒸し菓子）の製造が可能で ${ }^{15)}$ ，またかるかん原料 
としては生鮮物のックネイモでも粘度不足と言われてい る.このことを考えると, 今回調查した市販品は菓子業 者の要望を満たすものでないと評価できる.

\section{2. 各種ヤマノイモの凍結乾燥中における粘質多糖含}

1

ヤマノイモの凍結乾燥粉末の粘性がヤマノイモの種類 によって異なることは永島ら゙に によって報告されてい るが, Table 1 でも同じような結果を得ることができ た.

しかし、ヤマ/イモ「トロロ」の粘度は調製の方法に よって異なり，田附ら゙は卸し金とミキサーで調製した トロロでは後者の粘度の低いことを確認している．筆者 らもトロロの調製法によってもたらされる粘度の相違が 粘質多糖の娍少に起因するすのかを検証するため，卸し 金と高速磨砕機 (Comitrol, URSHEL JAPAN CO. LTD）で調製したトロロの物性と粘質多糖含量を求めた が, Table 2 に示すように，物理的性質は変わっても粘

Table 1 Apparent viscosity of freeze-dried yams

\begin{tabular}{|c|c|c|c|c|}
\hline \multirow{2}{*}{\multicolumn{2}{|c|}{ Sample }} & \multicolumn{3}{|c|}{ Apparent viscosity (mPa.s) } \\
\hline & & $1 \mathrm{rpm}$ & $10 \mathrm{rpm}$ & $100 \mathrm{rpm}$ \\
\hline \multicolumn{2}{|c|}{ Freeze-dried Jinenjo } & 185 & 32 & 9 \\
\hline \multicolumn{2}{|l|}{ Soro-yam } & 530 & 94 & 24 \\
\hline \multicolumn{2}{|c|}{ Tsukune-imo } & 170 & 30 & 8 \\
\hline Freeze-dried yam & (1) & 120 & 25 & 7 \\
\hline \multirow[t]{2}{*}{ on the market } & (2) & 120 & 15 & 4 \\
\hline & (3) & 130 & 24 & 7 \\
\hline
\end{tabular}

Freeze-dried yam was rehydrated until water content reached $87.3 \%$.
質多糖含量に変化のないことを確かめることができた. 凍結乾燥過程におけるヤマ/イモの粘度低下の原因 が, 凍結乾燥工程中で与えられる物理的衝擊によるのか または粘質多糖の量的変化によるものかについては明確 にされていない，そこでジネンジョ，ックネイモ，ソロ ヤ厶の凍結乾燥前後における粘質多糖含量を調へ, Fig. 1 に示した. ジネンジョの粘質多糖は乾燥前の $586 \mathrm{mg} /$ $100 \mathrm{~g}$ から乾燥後にはその $62 \%$ に当たる $365 \mathrm{mg} / 100 \mathrm{~g}$ に滅少した. しかし、ックネイモとソロヤムでは涷結乾 焻前後における粘質多糖含量にほとんよ゙変化がなく，こ れらのヤマ/1モ粘質多糖は凍結乾燥に対し耐性がある ように見受けられた。

しかし, ジネンジョ、ックネイモ,ソロヤムから抽出,

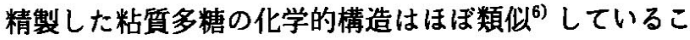
とを考えると、ヤマノイモの中に粘質多糖を安定化させ

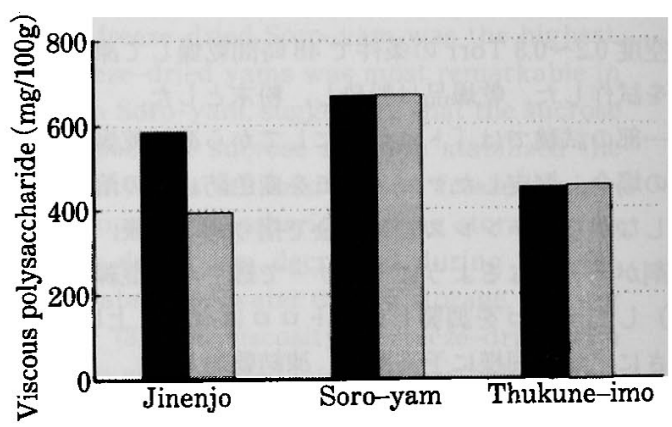

Fig. 1 Viscous polysaccharide content in fresh and freeze-dried yams

Fresh yam

Freeze-dried yam

Table 2 Properties of Tororo prepared by different methods

\begin{tabular}{ccc}
\hline Property of Tororo & $\begin{array}{c}\text { Mild homogenizer } \\
\text { (Orosi-gane) }\end{array}$ & $\begin{array}{c}\text { High speed homogenizer } \\
\left(\text { Comitrol }^{* * *}\right)\end{array}$ \\
\hline Mechanical characteristics* & & 7.5 \\
L value (cm) & 11.5 & 15.7 \\
S value $\left(\mathrm{cm}^{2}\right)$ & 65.6 & 379 \\
Viscous polysaccharide & 395 & \\
content $(\mathrm{mg} / 100 \mathrm{~g})^{* *}$ & &
\end{tabular}

* T-type hook was inserted into Tororo and then moved upward till rupture point of Tororo thread. L value and S value were distance and work.

** Separated by gel permeation column chromatography and determined with phenol- $\mathrm{H}_{2} \mathrm{SO}_{4}$ method.

*** URSHEL JAPAN Co., LTD. 
る他の要素の含まれる可能性が高い，凍結乾燥前後のヤ マ/イモ水抽出物のゲル滤過パターンでは，低分子域に 溶出する炭水化物量がヤマノイモの種によって大きく異 なったが, ペーパークロマトによって殆どが蔗糖である ことを確かめた. その含量はジネンジ $=0.2 \%$, ックネイ モ2\%、ソロヤムで 4\%であった. ヤマノイモの凍結乾 燥耐性との関連で見てみると, 可溶性糖の少ないものに おいて粘度低下が大きくなった。

3. 凍結乾嬠粉末の粘度保持に対する庶榶添加の効果

ヤマノイモの凍結乾燥耐性と可溶性糖含量との関連性 を確かめるため, 東結乾燥粉末の粘度低下の激しかった ジネンジョを供試し，蔗糖添加の効果を検討した。 ジネ ンジョを濖り卸してトロロとし，トロロに対し，蔗糖を 2〜10\% 加え，よく混練した後凍結乾嬠した。 この試験 においては，涷結乾燥完了後直ちに水戻ししたものを凍

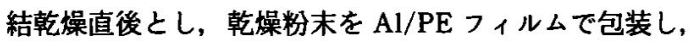
$30^{\circ} \mathrm{C}$ で 1，2，3 日間保管したものと区別した.

Fig. 2 に示すように凍結乾燥直後においては，加糖し ない時でも粘度が低下することはなかったが, 倲結乾燥 品を眝蔵する過程において，無加糖区は眝蔵 1 日後に約 1/2，2 日後に $1 / 3$ に減少した. $2 \%$ 加糖区では眝蔵 2 日 目から粘度低下が起こり，4\% 以上加糖すると粘度が安 定することが明らかとなった. 永島ら ${ }^{13)}$ はイチョウイモ の東結乾燥品の粘度改善に, ブドウ糖, デキストリン, でん粉, カゼインナトリウムの添加が效果的であったと 報告しているが，庶糖を含めたこれらの水和性の高い成 分がヤマノイモの東結乾燥粉末の粘度を安定させる要因 になっていると考えられる.

Table 1 の凍結乾燥ジネンジョと Fig. 2 の凍結乾燥直
後の見掛け粘度に差がみられるが,この差は Table 1 の 試験の段階では，眝蔵中における急速な粘度減少が明ら かにされておらず, 凍結乾燥完了後 2 3 日後に水戻し して粘度測定したことにも原因があると考えられる。

\section{4. 凍結乾嬠粉末の貯蔵条件之粘度変化}

ヤマノイモの凍結乾燥品は業務用から個人消費用向け の製品が出回り, 包装単位量, 包装資材も異なっている. またこれらの製品は常温下で流通されている.

凍結乾燥粉末の粘度が眝蔵中に急減することは石谷 ら ${ }^{10)}$ が報告している. Fig. 2 の結果も, ヤマノイモ凍結 乾燥粉末の粘度低下が凍結乾燥工程よりあその後の眝蔵 過程において起こることを示している.

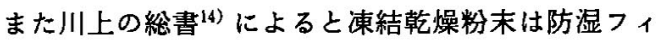
ルムにいれ $20^{\circ} \mathrm{C}$ におくとあり，眝蔵中の管理の重要性 がうかがわれる. そこで, 凍結乾燥粉末の粘度が比較的 安定していたソロヤムについて，眝蔵温度と包装資材が 粘度に及ぼす影響を検討した。

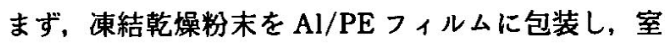
温, $5^{\circ} \mathrm{C},-20^{\circ} \mathrm{C}$ で眝蔵し, 凍結乾燥前の水分含量まで水 戻ししたヤマノイモトロロの粘質多糖含量および水抽出 液の見掛け粘度測定結果を Table 3 に示した。

眝蔵温度が粘度变化に及ぼす影響は大きく，室温で 1 年間貯蔵した凍結乾燥粉末抽出液のゲル滤過では粘質多 糖に相当するピークが検出されず，その含量は求められ なかった。

$5^{\circ} \mathrm{C}$ 眝蔵においても若干の粘度低下は避けられず, 一 $20^{\circ} \mathrm{C}$ 眝蔵で長期にわたる粘度保持が可能となった. 以上 の結果を踏まえて考えると, 市販品のヤマ/イモ倲結乾 燥粉末に指摘される品質のバラッキは，流通過程におけ

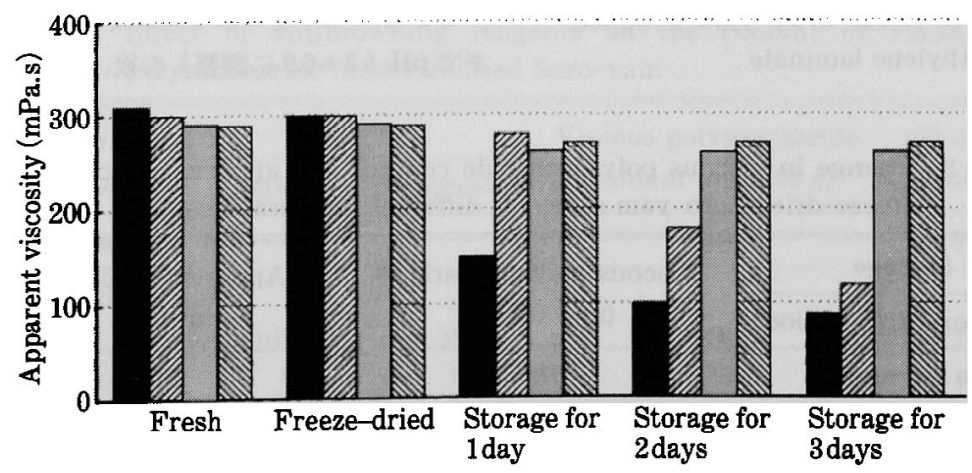

Fig. 2 Effect of sugar addition on the viscosity of freeze-dried Jinenjo

Sugar addition $0 \% \square$ Sugar addition $2 \%$

Vugar addition $4 \% \mathbb{N}$ Sugar addition $10 \%$ 
る温度条件および眝蔵期間の長さにも起因すると言え る.

次に水蒸気透過性の異なる $\mathrm{Al} / \mathrm{PE} フ ィ ル ム と ~ \mathrm{Ny} / \mathrm{PE}$ フィルムで包装し, $20^{\circ} \mathrm{C}$ および $8^{\circ} \mathrm{C}$ で最高 6 か月眝蔵し た時の凍結乾燥粉末の水分含量および見掛け粘度を Fig. 3 に示した.

凍結乾燥粉末の水分含量は眝蔵前で $4.1 \%$ であった が， $\mathrm{Ny} / \mathrm{PE}$ で包装したとき， $20^{\circ} \mathrm{C}$ で 5 か月眝蔵後に $11.5 \%, 8^{\circ} \mathrm{C}$ で 6 か月眝蔵後に $13.8 \%$ に達した. 眝蔵庫 内の湿度を测定していないので明確なことは言えない が, 調湿機能を持たない冷葴庫のため, 相対湿度が高く，

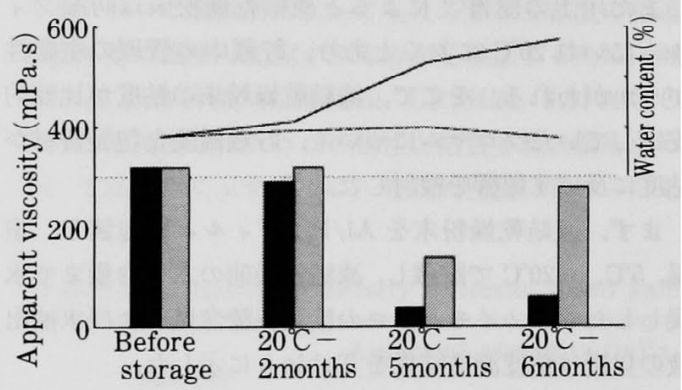

Fig. 3 Influence of wrapping methods on the apparent viscosity of freeze-dried Soro-yam

Apparent viscosity of freeze-dried yam wrapped in aluminium-polyethylene laminate

Apparent viscosity of freeze-dried yam wrapped in nylon-polyethylene laminate Water content of freeze-dried yam wrapped in aluminium-polyethylene laminate

- Water content of freeze-dried yam wrapped in nylon-polyethylene laminate
凍結乾燥粉末の吸湿が多くなったように思われる。一 方, 水蒸気透過性の殆どない $\mathrm{Al} / \mathrm{PE}$ 区での水分含量の 変化は，最も多いもので $0.6 \%$ の増加で，眝蔵中の吸湿 を抑えるためには水分透過に対するバリアー性がアルミ ラミネートフィルムに匹敵する程度の包装資材が要求さ れることがわかった。

$20^{\circ} \mathrm{C}$ 貯蔵で見掛け粘度に変化が見られたのは， 5 か月 眝蔵後で, Ny/PE フィルム区が眝荿前粘度の $12 \%, \mathrm{Al} /$

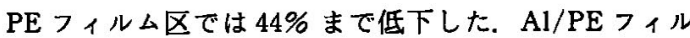
ム区では高温眝蔵に起因する粘度低下のみであるが,

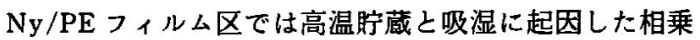
的な粘度低下のあったことが同える。

$8^{\circ} \mathrm{C}$ で 6 か月眝蔵したときの粘度低下は, $\mathrm{Ny} / \mathrm{PE} フ ィ$

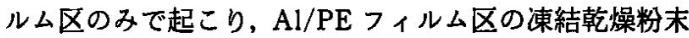
は眝蔵前之変わらない品質に保持された．低温下で眝蔵

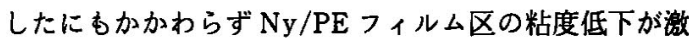
しかったのは, 館蔵中の吸湿があったためで, 乾燥粉末 の水分含量は眝蔵前より約 $10 \%$ 多い $13.8 \%$ に達した.

以上のことから，ヤマノイモ凍結乾嬠粉末の眝蔵中に おこる粘度低下を抑制するには水蒸気透過を遮断できる 包装資材で包装し，流通期間の長さに応じて低温眝蔵す ることが重要と言える。

5. トロロの pH が凍結乾煤粉末の粘度に及ぼす影需 ヤマノイモは変色しやすいため, 凍結乾燥前に変色防 止処理がなされる場合がある．変色防止剤としては亜硫 酸, ビタミンC等が使用されるが，トロロの $\mathrm{pH}$ の変動 要因になり得る. 一方，ヤマノイモの粘質多糖は電解質 としての性質を持ち ${ }^{(6)}$ ，塩酸添加によって沈殿する1).こ のことは $\mathrm{pH}$ が粘質多糖の安定化にかかわることを示唆 する.

そこで, ソロヤムのトロロを $0.1 \mathrm{~N}$ 塩酸, カセイソー ダで $\mathrm{pH} 5.6 \sim 6.9$ に調整した後，凍結乾燥したときの粘

Table 3 Change in viscous polysaccharide content and apparent viscosity of freeze-dried Soro-yam stored at different temperatures

\begin{tabular}{lcc}
\hline \multicolumn{1}{c}{ Storage } & $\begin{array}{c}\text { Viscous polysaccharide } \\
(\mathrm{mg} / 100 \mathrm{~g})\end{array}$ & $\begin{array}{c}\text { Apparent viscosity } \\
\text { (mPa. s) }\end{array}$ \\
\cline { 1 - 2 } Temperatures-period & 670 & 544 \\
Before storage & 428 & 380 \\
RT-5 months & n.d. & 100 \\
RT-12 months & 478 & 498 \\
$5^{\circ} \mathrm{C}-12$ months & 582 & 520 \\
$-20^{\circ} \mathrm{C}-12$ months & & \\
\hline
\end{tabular}

n.d : not detected. 
性変化を比較した。

Fig. 4 に示すように，凍結乾燥前トロロの見掛け粘度 は， $\mathrm{pH}$ の上异に従い高くなる傾向を示した。

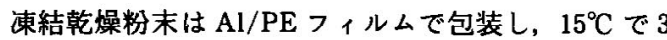
か月眝蔵した後乾嬠前の水分含量まで水戻しした．凍結 乾燥前トロロの見掛け粘度を 100 とした場合の凍結乾燥 品眝蔵後の見掛け粘度は, pH 5.4 で 43, pH 5.9 で 48, pH 6.4 で 78, pH 6.7 で 83 となった.

次に変色防止を目的に，トロロに亜硫酸を $28 \mathrm{ppm} お$ よびビタミン C を $0.2 \%$ 加えた後凍結乾燥した時の粘質 多糖の変動を比較し, Table 4 に示した.

生鲜物卜口ロの $\mathrm{pH}$ は 6.0 であったが，ビタミンCを 添加することによって 5.4 に低下した。一方亜硫酸添加 区では添加量が少ないためか $\mathrm{pH}$ の変動はなかった。

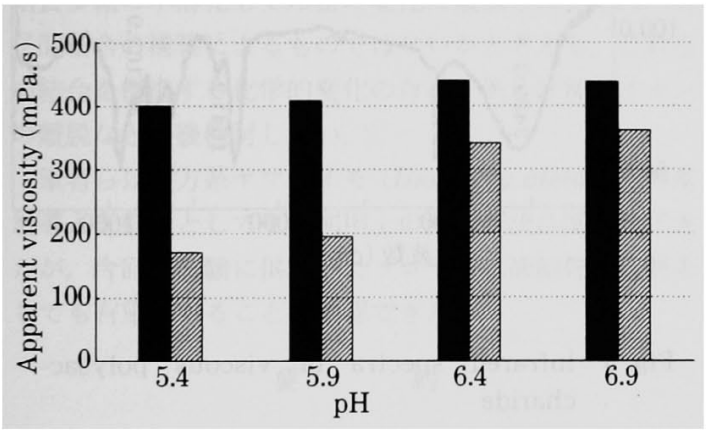

Fig. 4 Effect of $\mathrm{pH}$ on the apparent viscosity of fresh and freeze-dried Soro-yam

Apparent viscosity of fresh Soro-yam

Z Apparent viscosity of freeze-dried Soroyam stored for 3 months at $15^{\circ} \mathrm{C}$
凍結乾燥前の粘質多糖含量は $549 \mathrm{mg} / 100 \mathrm{~g}$ であった が, ビタミンCを加えて凍結乾燥し, $30^{\circ} \mathrm{C}$ と $5^{\circ} \mathrm{C}$ で 2 か 月眝蔵した後は，それぞれ $105 \mathrm{mg} / 100 \mathrm{~g}$ と $250 \mathrm{mg} / 100$ $\mathrm{g}$ に減少した。

亜硫酸添加区は, $30^{\circ} \mathrm{C}$ で 2 か月眝荿後に $169 \mathrm{mg} / 100$ $\mathrm{g}$ まで減少したが, $5^{\circ} \mathrm{C}$ 眝蔵での粘質多糖の減少はごく 僅かであり， 1 年間に亘る長期眝蔵も可能であった。

このように凍結乾燥前にヤマ/イモの $\mathrm{pH}$ を酸性側に 移行させることは凍結乾燥粉末中の粘質多糖を変質さ せ，粘度低下を促進させることがわかった。

ヤマノイモの粘質多糖は酸によって沈殿するが，この 沈殿物は水不溶である。一方，エタノールでは水可溶の 沈殿が得られる.両者の化学成分の邉いは灰分量で，池 尾 ${ }^{17)}$ によると塩酸，酢酸による沈殿物中にはカリウムが $0.4 \%$ ，エタノールによる沈殿物中には $5.75 \%$ 含まれる。 粘質多糖中の灰分はイオン交換樹脂によって除去でき, イオン的に結合していると思われる ${ }^{6)}$ ：以上のことから 推測できることは，イオン的に結合している無機成分が 少なくなると粘質多糖は水不溶になるように思われる. すなわち，粘質多糖は無機イオンと結合して安定した分 子構造となっているが, 酸性になると無機イオンが粘質 多糖より離脱するため，分子内または分子間会合が起こ り，水不溶になる機構が推測される．凍結乾燥粉末の $\mathrm{pH}$ が低くなるに従い粘度低下が促進されるのは，粘質 多糖からの無機イオンの離脱の程度が異なるためではな いかと考えられる.これについては今後検討したい．

\section{6. 精製粘質多糖の凍結乾燥，貯蔵過程中の変黄}

凍結乾燥されたヤマ/イモの粘度低下の機構は明らか にされていない，粘度低下の著しいヤマ/イモ凍結乾燥

Table 4 Effect of antibrowning reagents on the content of viscous polysaccharide in freeze-dried Soro-yam

\begin{tabular}{|c|c|c|c|c|}
\hline \multirow{2}{*}{$\begin{array}{c}\text { Antibrowning } \\
\text { reagent }\end{array}$} & \multicolumn{2}{|c|}{ Storage } & \multirow{2}{*}{$\begin{array}{l}\text { Viscous polysaccharide } \\
\text { content }(\mathrm{mg} / 100 \mathrm{~g})\end{array}$} & \multirow{2}{*}{$\begin{array}{l}\mathrm{pH} \text { of } \\
\text { Tororo }\end{array}$} \\
\hline & Period & Temperature & & \\
\hline Fresh yam* & & & 549 & 6.0 \\
\hline \multicolumn{5}{|c|}{ Freeze-dried yam } \\
\hline \multirow[t]{4}{*}{$\mathrm{SO}_{2}$} & 2 months & $30^{\circ} \mathrm{C}$ & 169 & 6.1 \\
\hline & & $5^{\circ} \mathrm{C}$ & 503 & 6.1 \\
\hline & 12 months & $5^{\circ} \mathrm{C}$ & 465 & 5.9 \\
\hline & & $-20^{\circ} \mathrm{C}$ & 531 & 6.0 \\
\hline \multirow[t]{2}{*}{$\mathrm{VC}$} & 2 months & $30^{\circ} \mathrm{C}$ & 105 & 5.4 \\
\hline & & $5^{\circ} \mathrm{C}$ & 250 & 5.4 \\
\hline
\end{tabular}

* Fresh yam did not contained antibrowning reagent. 
粉末の水抽出液のゲル滤過においては，粘質多糖に相当 するピークが見られなくなった。このことは，粘質多糖 が低分子化するか不溶性になることを示唆している。そ こで，精製した粘質多糖を涷結乾燥し，眝蔵した時の状 態変化と化学成分的な変化を検討した。

精製粘質多糖の $0.01 \%$ 水溶液を調製し，遠心分離した 上澄液の相対粘度は Table 5 に示した。凍結乾燥前の 3.16 に対し, 凍結乾燥直後は 3.03 となり, 倲結乾燥過程 における粘度低下は僅少であった。しかし室温下で 1 か 月眝蔵することによって粘度は激減し，相対粘度は 1.21 となった. この区の粘質多糖は水戻ししても溶解するこ とがなく，不溶化する減少を捉えることができた.

ヤマノイモ枮質多糖はアセチル化したマンナンと蛋白 との複合体で,このためにマンナンに親水性が与えられ ると言われる3). 従って，不溶化にはこれらの成分変化 を伴うことが予測される.

精製粘質多糖 $0.01 \%$ 水溶液を遠心分離し，上澄液中の タンパク質と炭水化物量を求めたところ, 凍結乾燥前で は $0.24 \mathrm{mg} / 100 \mathrm{ml}, 0.72 \mathrm{mg} / 100 \mathrm{ml}$ となり，その比は 0.33 であった. 室温下で 1 か月眝蔵した粘質多糖は水不 溶となったように見受けられたが，全ての粘質多糖が沈 殿するのでなく，上澄液中にタンパク質が $0.11 \mathrm{mg} / 100$ $\mathrm{m} l$, 炭水化物が $0.25 \mathrm{mg} / 100 \mathrm{~m} l$ 含まれた. 蛋白/炭水化 物比は 0.39 となり，上澄液中には蛋白を多く含む粘質多 糖が含まれることがわかった，すなわち，変性した粘質 多糖には不溶化する成分と不溶化しにくい成分があり， 後者は蛋白に富んでいるように思われる。これらの成分
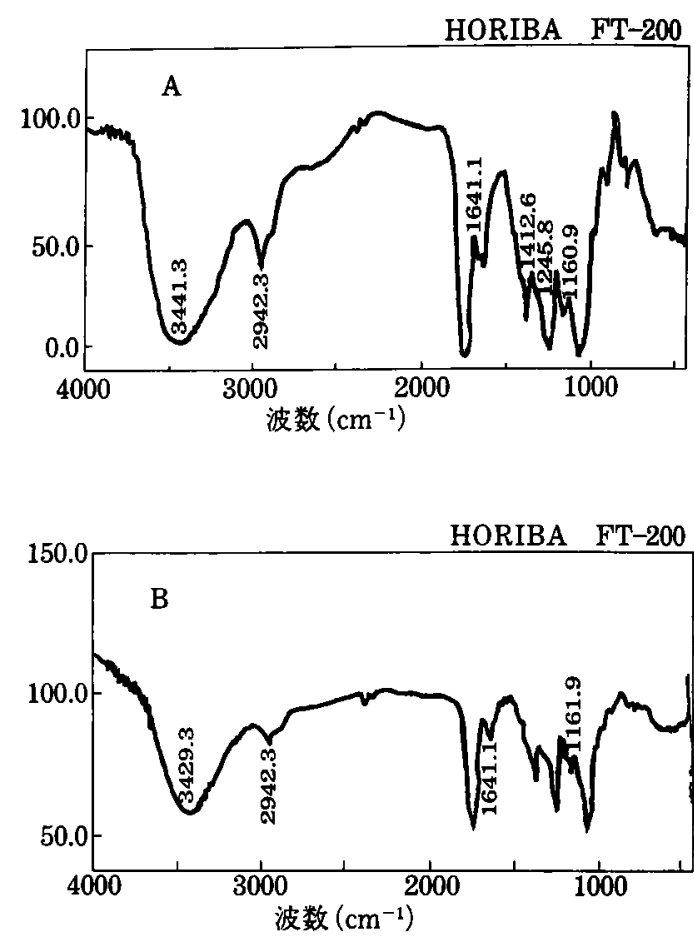

Fig. 5 Infrared spectra of viscous polysaccharide

A : Water soluble viscous polysaccharide

$B$ : Water insoluble viscous polysaccharide

Table 5 Change in relative viscosity of freeze-dried viscous polysaccharide

\begin{tabular}{lcccc}
\hline \hline & Relative & \multicolumn{3}{c}{ Content in supernatant $(\mathrm{mg} / 100 \mathrm{ml})$} \\
\cline { 3 - 5 } Process and storage & viscosity & $\begin{array}{c}\text { Protein } \\
(\mathrm{A})\end{array}$ & $\begin{array}{c}\text { Carbohydrate } \\
\text { (B) }\end{array}$ & $\mathrm{A} / \mathrm{B}$ \\
\hline Before freeze drying & 3.16 & 0.24 & 0.72 & 0.33 \\
$\begin{array}{l}\text { After Storage } \\
\text { 0 day }\end{array}$ & 3.03 & & & \\
1 month at RT & 1.21 & 0.11 & 0.28 & 0.39 \\
at $-20^{\circ} \mathrm{C}$ & 3.11 & 0.21 & 0.60 & 0.35 \\
\hline
\end{tabular}

Viscous polysaccharide was extracted from Jinenjo, purified with SDSEthanol five times and then freeze dried. Freeze dried viscous polysaccharide $(10 \mathrm{mg}$ ) was added to $100 \mathrm{ml}$ of water with stirring. Mixture was stirred for 10 hours at $5^{\circ} \mathrm{C}$ and then centrifuged $(10000 \mathrm{rpm}, 10 \mathrm{~min})$. Relative viscosity of the supernatant was measured with Ostowald viscometer. Protein and

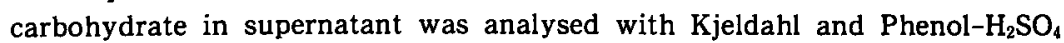
method. 
がもともと含まれていたのか，粘質多糖の変性の結果生 成されたものなのか定かでないが，タンパク質が粘質多 糖の女定性に関与することを示唆している。

アセチル基については凍結乾燥直後の水可溶精製粘質 多糖と室温下で 1 か月貯蔵した粘質多糖を水に溶かし， 水不溶部のみを回収してその赤外吸収スペクトルを比較 した．Fig. 5 に示すようにどちらにもェステル結合に由 来すると言われる $1738 \mathrm{~cm}^{-1}$ 付近の吸収があり, 脱了 セチル化を示唆するすのでなかった．これらの置換基の 定量を行っていないので，凍結乾嬠したヤマ/イモ粘質 多糖の粘度低下が化学的成分変化に基づくものでないこ とを実証するに至らないが，凍結乾燥粉末の粘度变化 が, 水分含量, $\mathrm{pH}$, 眝蔵温度, 親水性物質の存在によ。 て左右されることは前述したとおりであり，ヤマ/イモ 粘質多糖の不溶化もでん粉の老化に類似した分子内, 分 子間結合の構築によるものではないかと考える。これら の結合を促進する化学的変化の存在, 例えば無機イオン の離脱など今後検討したい。

筆者らは南方系ヤマノィモ（Dioscorea alata L.) の産 地導入を前提としてその利用上の問題解決に関わってき たが, 今回の試験に供試したソロヤムは凍結乾燥素材と してあ有望であることを確認できた。

\section{要約}

ヤマ/イモの涷結乾燥粉末の粘度に及ぼす要因とし て, ヤマノイモの種類, 倲結乾燥前のヤマノイモの $\mathrm{pH}$ および涷結乾燥粉末の眝蔵条件について検討した。

(1) 種の異なるジネンジョ (Dioscorea japonica Thunb), ックネイ (D. opposita Thunb), ソロヤム (D. alata L.) の凍結乾燥粉末の粘度低下はジネンジョ が最も大きく、ソロヤムが安定していた。ジネンジョの 粘度低下の一因として可溶性糖含量の少ないことが考え られ, シネンジョに4\% 加糖して凍結乾燥した粉末の粘 度は安定化した。

（2）東結乾燥粉末の粘度低下は，乾燥工程中より， そ の後の眝蔵過程において起こる度合いが高かった. 眝蔵 中の粘度低下は眝蔵温度が低いほど抑制された。 また涷 結乾燥粉末は水蒸気透過性の少ないフィルムで包装し,
吸湿させないことが粘度保持上重要になることが判っ た.

(3) 凍結乾燥前にヤマ/イモの $\mathrm{pH}$ を酸性側に変動さ せると凍結乾燥粉末の粘度低下は促進された。

(4) 逨結乾燥粉末の粘度低下は粘質多糖の不溶化に起 因すると推測された。

終わりに，本稿を草するにあたり，数々のご助言と御 検閲を睗った永演伴紀鹿児島大学名誉教授に厚くお礼申 し上げます。

\section{文献}

1）高橋悌蔵 : 農化, 4, 648 (1928).

2）佐藤利夫 : 日化誌， 88，982（1967）.

3）佐藤利夫：日化誌， 88，985 (1967).

4) M, A. I, T. and H, T. : Agric. Biol. Chem. 36, 761 (1972).

5）弘中和憲 - 高田勝義・石橋憲一 : 日食工誌，37, 48 (1990).

6）田之上隼雄 -下園英俊：日食工誌，38，751 (1991).

7）清水美智子・外山マサ・田附きつ：New Food Industry, 21, 41 (1978).

8）田附きつ: 家政誌, 33, 329 (1982).

9）弘中和憲 ·高田勝義・石橋憲一: 日食工誌, 36, 891 (1989).

10）石谷 孝・小城年久·木村 進 : 食品総合研究所 研究報告, 28, 88 (1973).

11）永島俊夫・斎藤紀子・谷口行夫・鴨居郁三 : 日本 食品低温保蔵学会誌, 22, 73 (1996).

12）田之上隼雄・穗原関夫・石畑清武：日食工誌， 35,595 (1988).

13）永島俊夫・鴨居郁三：日本食品工業学会講演要旨 集，P. 129，東京 (1990)。

14）川上幸次郎編著：ヤマノイモ百科，富民協会，大 阪, 160 (昭和 43 年).

15）田之上隼雄・下園英俊・迫田隆仁：日食工誌， 40, 627 (1993).

16）佐藤利夫・水口 純-鈴木周一・戸倉正利：日化 誌, 88，216 (1967).

17）池尾和子 : 奈良学芸大, 12, 15 (1964).

(平成 9 年 8 月 4 日受付, 平成 9 年 12 月 22 日受理) 